\title{
GUIDE TO THE INTERNATIONAL ARCHIVES AND COLLECTIONS AT THE IISH: SUPPLEMENT OVER 2010*
}

In 2000 a new edition of the 'Guide to the International Archives and Collections at the IISH, Amsterdam' (henceforth cited as GIA) was published. A description of recently acquired archives and collections as well as major accruals to archives received by the IISH will be published annually to keep this survey up to date. Like the GIA this supplement is subdivided into the categories 'persons', 'organizations', and 'subjects', arranged alphabetically.

As to the summaries the following components can be discerned:

I. Access: As a rule consultation is not restricted; any restrictions are indicated by*.

2. Name: Names of persons include dates of birth and death when known. In the case of international organizations with names in more than one language, the name chosen corresponds to the language in which most of the documents were written. Among organizations that have changed their names, the one used most recently was selected. Previous names of organizations are mentioned in the condensed biography or history. The names of subject collections are mostly in English.

3. Period: First and last date of the documents present. Where only a few documents are from a certain year or period, they are listed between parentheses.

4. Size: In linear metres.

5. Finding aid: Available inventories, lists, and indexes.

6. Biography/history: A condensed biography or history of the persons or organizations concerned.

7. Summary of the contents: A summary of the contents of the archives, papers or collection concerned.

Reference is given to the pages of the GIA holding the initial description where summaries of an accrual are concerned.

The summaries of this supplement will also be added to the survey of archival collections on the Internet website of the IISH (http://www.iisg.nl). Summaries of the Dutch collections of the IISH can be found in the survey on the Internet website too.

The archives may be consulted in the reading room of the IISH. Requests for documents should include their inventory or list numbers. For further information about the rules for access and consultation (including rules on procedures for handling the material and making photocopies) users should contact the information service of the IISH (e-mail: ask@iisg.nl). 


\title{
I. Persons
}

\author{
Dähne, Eberhard (1938-2010) \\ Period: $1940-2010$ \\ Size: $8 \mathrm{~m}$.

\section{Finding aid: preliminary list}

Born in Freienwalde, Brandenburg, Germany 1938, died in Frankfurt am Main 2010; alone, at the age of fifteen, he left the German Democratic Republic; went to Kiel to study agricultural science and became involved in the Sozialistischer Deutscher Studentenbund (SDS), becoming chairman in I96I; as a member of the SPD active in the Socialist Youth organization 'Die Falken' (The Falcons); the SPD and SDS split because of divergent views on the perspectives of left wing policy in Western Germany 1961; expelled by the SPD 1962; settled in Marburg and became a close colleague of Wolfgang Abendroth 1963; participated between I966 and I968 in an unsuccessful initiative to establish an alternative leftist SPD; founded the Institut für Sozialwissenschaftliche Forschung (Institute for Scholarly Social Research) 1968; was active in Marburg in the local branch of the Deutsche Kommunistische Partei (DKP, German Communist Party) and various trade unions; got his Ph.D. in philosophy 1972; staff member of the Institut für Marxistische Studien und Forschungen (Institute for Marxist Studies and Research) in Frankfurt am Main 1973-1989; specialized in municipal government and published the standard work Gemeindeleute about red and green alternatives in the community politics in the Federal Republic of Germany; left the DKP I989; city councillor in Frankfurt am Main 200I-2006 as a representative of the Partei des Demokratischen Sozialismus (PDS), although he was not a member of this party.

Personal documents I940-1992; correspondence I982-2010; documents on the Sozialistischer Deutscher Studentenbund and his studies in Kiel and Marburg I960-I968; documents concerning the Institut für Sozialwissenschaftliche Forschung (ISF) in Marburg 1967-I993; documents concerning the Deutsche Kommunistische Partei (DKP), especially on the Marburg section and the Westend district in Frankfurt am Main 1972-1990; documents concerning the project 'Frankfurt Arbeit und Leben (FAUL) 2000' I987, the history of Hessen 1990-2000, the regional economic development of Thüringen I994-I998, the common strategy of government, employers' organizations and trade unions 'Bündnis für Arbeit' I995-2000, and the historiography of the revolution year I968 2007-2008; declarations by and press clippings on the SPD politician Herbert Wehner I946-I997.

\section{Dosdoğru, M. Hulûsi (born I9I 5) \\ Period: 193 I-I 973 \\ Size: $0.12 \mathrm{~m}$.}

Born in Istanbul, Turkey 191 5; published magazine Inanç in 1938; graduated from the Faculty of Medicine 1940; published articles in the magazines Tan, Yig̈in, Yön, Ocak, Ant, Yeni Edebiyat, Yeni Insan; arrested in 1946, 1953, and 1955 for his leftist activities; his wife Dr. Sabire Dosdoğru (also born in Istanbul I9 I s) was a member of the Turkish Peace Association (Türkiye Barişseverler Derneği).

'T.C. Istanbul Belediyesi. Yazi Işleri Müdürlüğ̈̈' (a folder with forms filled in by patients) 1944-1949; two volumes 'Hasta Protokol Defteri, Protokol Kayıtları' (Register of the patients) (1956) I957-1959, I964-1969; two typescript versions of the novel 'Yitik' ('Missing') n.d.; some correspondence, manuscripts, and typescripts and other documents I93 I, I95 I, I953, I966, I971 and 1973. 


\section{Hondt, Jacques d' (born 1920) \\ Period: $194 \mathrm{I}-2008$ \\ Size: $8.25 \mathrm{~m}$.}

Born in Tours, France 1920; French philosopher specializing in the German philosopher Georg Wilhelm Friedrich Hegel (1770-I 83 I); studied philosophy at the University of Poitiers and taught at various Lyceums from I94I; gained two Ph.Ds: 'Hegel, philosophe de l'histoire vivante', primary thesis judged by Jean Hippolyte, and 'Hegel secret. Recherches sur les sources cachées de la pensée de Hegel', secondary thesis judged by Paul Ricoeur, both in 1946; taught at the University of Poitiers from 1964 and was professor in philosophy at the same University 1969-1987; founded the Centre de Recherche et de Documentation sur Hegel et Marx 1970, being its director until 1975; President of the Société Française de Philosophie 1982-1995; President of the Association des Sociétés de Philosophie de Langue Française 1988-1996; member of the Board of the Internationale Hegel-Vereinigung and from 1982 corresponding member of the Sächsische Akademie der Wissenschaften; Jacques d'Hondt became an expert in Hegel's philosophy while studying Marx and published a lot of articles and about twelve books on Hegel including a biography.

Correspondence and other documents concerning his activities at the University of Poitiers I969-I99I, at the Centre de Recherche et de Documentation sur Hegel et Marx 1964-1999, at the Société Française de Philosophie 1980-2000, and at the Association des Sociétés de Philosophie de Langue Française 1988-I997; correspondence, reviews, and other documents concerning his publications in France 1982-2003; correspondence and other documents concerning the translation of his work in various languages 1972-1983; correspondence with colleagues and students in China, Italy, Japan, Romania, and other countries 1982-1995; correspondence and other documents concerning lectures and conferences in various countries 1970-1999; correspondence and other documents concerning Dom Deschamps i970-2008, Jean Hyppolite 1964-2003, and Fiorinda Li Vigni i989-2006; 'Spinoza et la finalité', mémoire de maîtrise of Jacques D’Hondt 1943; notes, drafts, manuscripts, and typescripts on various persons and subjects such as Marivaux, Rousseau, Diderot, Kant, Fichte, Hegel, Marx, Heidegger, Enlightenment, Illuminism, Utopia, Dialectics and Revolution, and Politics and Terror.

\section{Kendall, Walter (1926-2003)}

Period: 1953-1995

\section{Size: $25 \mathrm{~m}$.}

Born in East Ham, London 1926, died 2003; managing editor of Voice of the Unions early 1960s; cofounder of the Institute of Workers' Control 1968; fellow of the Centre for Contemporary European Studies at Sussex University when he published The Revolutionary Movement in Britain I900-1921. The Origins of British Communism 1969; supported in the mid 1970s the European 'Common Market' which was unusual within the Left spectrum; published The Labour Movement in Europe 1975; worked for many years on his still unpublished magnum opus 'The World Revolution, the Russian Revolution and the Communist International I898-1935'.

Correspondence and scrapbooks with articles in the New Dawn, Railway Review, Socialist Leader, Tribune, Voice of the Unions, Avanti, Critica Sociale, and other periodicals 1956-1995; Vanguard pamphlets 1953-1958; correspondence relating to the campaign for the release of Len Wincott from a Siberian Prison Camp 1955-1957; correspondence with and photocopies of Bruno Rizzi's pamphlets 1962-I964; papers presented by Kendall and other documents on the National 
Workers' Control Conferences held in the UK and other conferences on Workers' Control I964-I984; documents on the Polish Solidarity Campaign I980-I984.

\section{Lertcharoensok, Yindee \\ Period: $\mathbf{1 9 8 8 - 2 0 0 0}$ \\ Size: I.I $2 \mathrm{~m}$.}

Finding aid: list

A Thai national, studied in Bangkok; later MA in Southeast Asian Studies from University of London School of Oriental and African Studies; worked with an INGO on a refugee resettlement programme; journalist with The Nation, an English-language daily paper in Thailand 1988-2000; her main subjects were Thai foreign diplomacy, South-East Asian current affairs, and political, economic, and social issues, including regional ethnic and territorial conflicts, drugs and arms smuggling, and refugees and human rights; was later on assistant editor, wrote commentaries and her weekly column 'From the Edge'; joined in 2000 UNESCO Regional Office in Bangkok working on projects, supported by the Asian Development Bank and the British government, on birth and citizenship registration and anti-trafficking of women and children in the Greater Mekong Sub-region; worked since March 2006 with an UN Office for the Coordination of Humanitarian Affairs - Regional Office for Asia and the Pacific in Bangkok.

In Thai language: documents on economic development, human rights, migrant workers, minority groups, natural resources and other topics; press releases from the Ministry of Foreign Affairs of Thailand 1988-2000.

In English language: documents on All Burma Students' Democratic Front (ABSDF), Amnesty International, Democratic Alliance of Burma (DAB), Human Rights Watch Asia, Karen National Union (KNU), League for Democracy and Peace (LDP), Myanmar Embassy in Bangkok, National Coalition Government of the Union of Burma (NCGUB), Union National Democracy Party (UNDP), US Committee for Refugees, and other organizations and issues related to Burmese and Thai society and the relations between both countries I988-2000.

\section{*Maddison, Angus (1926-2010)}

\section{Period: c.1950-c.2010}

\section{Size: $24 \mathrm{~m}$.}

Born in Newcastle-upon-Tyne, United Kingdom 1926, died in Paris 2010; Professor at the Faculty of Economics, University of Groningen, The Netherlands, and co-founder of the Groningen Growth and Development Centre; his career started in the late I940s; worked on a wide range of economic policy and development issues at the Organization for European Economic Cooperation (OEEC), the Organization for Economic Co-operation and Development (OECD) and under a variety of consultancy contracts; appointed to the Faculty of Economics at the University of Groningen to spend his time in researching the problems of economic growth and development 1978; published his autobiography Confessions of a Chiffrephile 1994.

Correspondence from the period he was working for the Organization for European Economic Cooperation (OEEC) and the Organization for Economic Co-operation and Development (OECD) I950s and I960s; correspondence and manuscripts on and resulting from his research on the Gross Domestic Product (GDP), looking at the phenomena of economic growth and development in various countries and eras c.I950-c.20I0. 
Malaquais, Jean (1908-1998)

Period: 1945-1996 (2009-20II)

Size: $0.37 \mathrm{~m}$.

Finding aid: inventory

Accrual; for initial description see GIA, p. I4I.

Correspondence with Serge Bricianer 1952-I954, Marc Chirik 1945-1978, Raya Dunayevskaya 1953-1964, Louis Evrard I953-1992, Julián Gorkin I946-1950, Jean van Heijenoort 1947, Louis and Sara Jacobs 1950-1960, Paul and Ilse Mattick I966-I98 I, Marceau Pivert 1946-I947, Alfred Rosmer n.d., Maximilien and Mania Rubel I957-1996, and Volin 1945; typescript 'La Dissolution de la GCF' by Antoine, pseudonym of Malaquais 1953, typescript 'Mai 1968' by Malaquais n.d.; typescript 'Politics and People. A Humanist Manifesto' by Joseph Church n.d.; typescript 'Marx' Labor Theory of Value' by Paul Mattick n.d.; minutes of meetings and other documents on the 'Conseillisme' (Workers' Council Movement) - group around Maximilien Rubel I950-1962.

${ }^{*}$ Mandel, Henri (Henoch) (1896-1953)

Period: 192 I-I953 (-1967)

Size: $0.5 \mathrm{~m}$.

Finding aid: inventory

Born in Wieliczka, near Cracow, Poland, in those days part of Austria-Hungary I 896, died in Brussels, Belgium 1953; departed for study reasons to Belgium I913; became diamond dealer and after the economic crisis of 1929-1930 insurance agent; had two sons: Ernest (Esra), born in Frankfurt am Main 1923, and Michel, born in Antwerp 1926; during World War II the family Mandel had to go into hiding; Henri Mandel and his sons were active in resistance groups: Henri Mandel was founder of the resistance group 'Vrank en Vrij' (Frank and Free), issuing the periodicals Het Vrije Woord (October 1940-August 1942), Das Freie Wort (January 1943-September 1944) and Vrank en Vrij (May 1943-September 1944); after World War II active in the 'Onafhankelijke Patriottische Groep' (Independent Patriotic Group) and the 'Nationale Unie van de Sluikpers' (National Union of the Clandestine Press), promoting the social, judicial and financial interests of people active in the resistance.

Correspondence 1943-1952; documents on insurances and compensations after World War II I939-I960; documents on the naturalization of Henri and Rosa Mandel I945-I952; documents on the activities of the resistance group 'Vrank en Vrij', the people belonging to it and its periodicals 1944-1953; documents on the 'Onafhankelijke Patriotische Groep' and the 'Nationale Unie van de Sluikpers' 1944-I953.

\section{Periáñez, Manuel (born 1940)}

Period: $1963-2006$

Size: $0.25 \mathrm{~m}$.

Born in the Dominican Republic into a Spanish-Republican family in exile I940; grew up in Venezuela, France, Belgium, and the Netherlands; initially studied in Milan and Delft, the Netherlands, but chose urban sociology at the Sorbonne University in Paris 1965-1969; also studied psychoanalysis (practice since 1975); influenced by Cornelius Castoriadis and Georges Devereux. 
Letters from Fritjof Tichelman 1963-2006; two letters from Maurice Ferares I978; typescripts on André Breton, Le Corbusier, Budapest 1956 and other subjects for the 'documents interieurs' of the Tendance Marxiste Révolutionnaire of the Fourth International (Tendency Michel Pablo) i964-I969.

\section{Strasser, Nadja (I87I-I955) \\ Period: N.d.}

Size: $0.02 \mathrm{~m}$.

Born as Noema Ramm in Starodub, Russia I 871, died in Berlin I955; writer and journalist; grew up in a small town in Russia, today north-east Ukraine, in an obvious anti-Semitic atmosphere; like her two sisters Alexandra and Maria left her native soil and went to Warsaw and later to Vienna; influenced by Zionism, Marxism, and Feminism; worked in Vienna and in Berlin as a journalist; published Die Russin on the special characteristics of Russian women I917 and Das Ergebnis on the role of women and the dominant relation pattern between men and women I918; left together with her partner Alexander Levy for Palestine 1920 but because of financial problems both went to Berlin 1927; both fled to Paris 1933; Levy was deported to Auschwitz in 1942 but Nadja Strasser survived in France and moved to London; after the liberation corresponded with Rudolf Rocker on the publication of her youth memoirs; returned in I95 I to Berlin, where she was a member of the 'Jüdische Gemeinde'.

Original typescript ( I76 pp.) of 'Von Etappe zu Etappe' (From Stage to Stage), the youth memories of Nadja Strasser on her child years in Russia and her acquaintance as a young woman with the ideas of Vladimir Medem and the 'Bund' and later the ideals of Zionism.

NB. This typescript is part of the collection 'Eastern Europe, various manuscripts'.

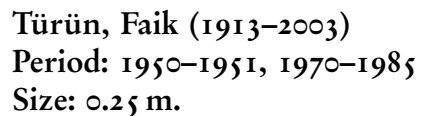

Born in Bursa, Turkey 1913, died in Istanbul 2003; joined the Turkish Armed Forces during the occupation of Japan 1950-I95 I; general in the Turkish Army; one of the leaders of the Turkish Counter-Guerilla from I97I, accused of torture practices; member of the Turkish Parliament for the Justice Party (Adalet Partisi, AP) from 1977.

Letters sent by Faik Türün from Japan to his family I950-195 I; incoming letters and invitations, notes and typescripts I970-I985.

\section{*Ward, Colin (1924-2010) \\ Period: (I 887-) I94I-2010 \\ Size: $7.87 \mathrm{~m}$.}

Finding aid: inventory

Born in Wanstead, Essex in 1924, died in Ipswich, Suffolk 2010; worked in architecture, planning and education; 5 years as a conscript in the army during World War II; afterwards he worked for architects and planners, and at the same time joined the editors of the newspaper Freedom in 1947; founded in 1961 the monthly journal Anarchy; became Education Officer for 
the Town and Country Planning Association 1971; was a prolific writer, chiefly on British social history and topics concerning the built environment; his many books include British School Buildings. Designs and Appraisals (1976), Anarchy in Action (1973), The Child in the City (1978), and Cotters and Squatters. The Hidden History of Housing (2004); much of his writing is around the theme of replacing authoritarian government with popular self-management; became an Honorary Doctor of Philosophy 200I.

Personal letters c. I96I-I979; correspondence with friends I980-2009; family correspondence I990-2009; miscellaneous correspondence 1980-2009; correspondence relating to architecture, housing, planning and self-build 1980-2009, to anarchism I980-2009, to books by Colin Ward and others I980-2009, and to journalism 2003-2005; lists of names of correspondents during 1980-2009; personal documents, including honorary degrees c. I959-2010; correspondence, contracts, and other documents concerning his books c.1922-20I0; documents concerning his publications on 'plotlands' c.190I-200I; typescripts and printed articles, lectures, and reviews c.1945-2006; files on persons i 887, c.1930-2008; files on subjects c.1914-2008; other documents c.1970-2005, printed articles by Ward c.1974-2010, scrapbooks with printed articles, reviews and press comments I943-I999; other documentation I96I-2010.

\title{
2. Organizations
}

\section{Azerbaijan Democratic Party. Region Meshkin Period: $1945-1946$ \\ Size: $0.12 \mathrm{~m}$.}

After the end of World War II a short-lived Soviet-backed client state was established in Iranian Azerbaijan with Tabriz as its capital; this Azerbaijan People's Government existed from November 1945 until November 1946; mid-December 1946 the Iranian army reentered Tabriz and ended the People's Government after a full year of its existence; many of the leaders took refuge in the Azerbaijan Soviet Republic.

Correspondence and other documents from and on the Azerbaijan Democratic Party in the Region Meshkin 1945-1946.

\author{
*Peace Advocates for Truth, Justice and Healing (Philippines) \\ Period: $1976-2007$ \\ Size: $1.25 \mathrm{~m}$. \\ Finding aid: list
}

Peace Advocates for Truth, Justice and Healing (PATH) was formed in 2002 and had its founding assembly in August 2003; pioneered in its focus on human rights violations by non-state armed groups; composed of survivors of torture, families, relatives and friends of victims missing or executed during the anti-infiltration campaigns within the Communist Party of the PhilippinesNew People's Army (CCP-NPA) in the I980s, PATH seeks truth and justice from the CPP-NPA and other Left blocs whose leaders were involved in the anti-infiltration campaigns.

Minutes of the meetings of the founding assembly of PATH 2003; minutes of the meetings of the steering committee and the council of leaders of PATH 2003-2006; documents on roundtable discussions 2004-2005; lists of victims, perpetrators, and 
informants 2003-2005; transcriptions of interviews with relatives and friends of victims 2003-2004; documents on the exhumations of victims in Cebu 2005-2006; preliminary PATH-report to the UN special rapporteur on the extrajudicial killings 2007; documents on the contacts with the embassy of the Netherlands and the Dutch NGO's Novib-Oxfam and X min Y Beweging 2003-2006; periodicals, publications, and other documents on the Communist Party of the Philippines-New People's Army, the Kabataang Makabayan and the League of Filipino Students 1978-I992.

\section{Student Federation of Thailand \\ Period: $1982-2004$ \\ Size: $0.62 \mathrm{~m}$. \\ Finding aid: list}

The Student Federation of Thailand's principle objective is to fight for student rights, and for democracy and peaceful leadership, and to join together with Myanmar students against the Myanmarese/Burmese government's human rights abuses.

Photocopies of correspondence, statements and other documents 1982-2004.

\section{Subjects}

\section{Ethnic Movements in Iran}

\section{Period: 1973-1991}

Size: $0.12 \mathrm{~m}$.

The Democratic Party of Iranian Kurdistan was founded in 1945 in Mahabad in Iran; with the help of the Soviets, the Mahabad Republic of independent Kurdistan was founded January 1946; it existed only for a short time, after one year the Iranian army came back; guerilla warfare in the border region of Iran and Iraq occurred 1967-1968; after the Iranian Revolution of 1978 the Democratic Party of Kurdistan conquered parts of Iranian Kurdistan but the Islamic Republic re-conquered these in August 1979; since then the organization of the Democratic Party of Kurdistan has been forced abroad.

Printed documents on ethnic movements in Iran especially on Democratic Kurdistan I973-I99I. 